\title{
A study of total serum alkaline phosphatase activity in men following partial gastrectomy
}

\author{
J. AMBler, A. G. GREEN, AND C. N. Pulvertaft \\ From the County Hospital, York
}

SUMMARY Total serum alkaline phosphatase (SAP) activity has been measured in 463 men with partial gastrectomy (Polya type), and in a control group of 271 men with vagotomy with pyloroplasty or gastroenterostomy.

An analysis of variance of the values in the range of 3.0 to $11.5 \mathrm{KA}$ units/100 ml showed that the enzyme serum activity is influenced by three independent factors: age, ABO blood group, and the type of operation. Marginally raised levels (12.0-17.0 KA units/100 ml) were found to be affected by the same factors, and it was concluded that these levels do not, usually, indicate either bone or liver disease. In 18 men the total serum alkaline phosphatase was over 17.0 KA units: 16 had Paget's disease of bone, and two had liver disease.

There have been a number of reports of raised SAP activity in patients who have been treated by Polya gastrectomy, but both the frequency and the cause have been disputed. Earlier workers (Jones, Williams, Cox, Meynell, Cook, and Stammers, 1962; Deller, Edwards, and Addison, 1963; and Clark, 1964) attributed the change to a subclinical osteomalaciac syndrome, but unequivocal evidence of bone disease was often lacking. In a large survey carried out by Morgan, Paterson, Woods, Pulvertaft, and Fourman (1965) it was shown that an SAP level of more than $17.0 \mathrm{KA}$ units following Polya gastrectomy could usually be explained either by the presence of Paget's disease of the bone or liver disease, but a cause for the marginally raised SAP levels was often lacking. They suggested the source of this fraction might be the gut. Although Yong (1966) found some evidence to support this suggestion, Pulvertaft, Luffman, Robson, Harris, and Langman (1967) were unable to confirm this hypothesis.

The problem has been reinvestigated using the same source of patients used by Morgan et al (1965).

\section{Patients and Methods}

The patients attended the gastric follow-up clinic at the York County Hospital, at yearly intervals, after having had their operation within the York group of hospitals. The survey was conducted over the years 1966 to 1968 inclusive so that each patient would be expected to attend the clinic at least twice during this period. All blood samples were collected at the weekly afternoon clinic under comparable conditions, whilst the patients were taking their normal diet. The sera were immediately separated and stored at $4^{\circ} \mathrm{C}$ until the following morning when the SAP was estimated. It was established that this storage did not influence the estimation.

TheSAPactivity was measured by the automated method of Morgenstern, Kessler, Auerbach, Flor, and Klein (1965). The sera were incubated with p-nitrophenyl phosphate substrate in 1-amino 2-methyl 1-propanol buffer of $p \mathrm{H} 10 \cdot 25$. PNitrophenol, liberated by the action of the enzyme, was dialysed into a fresh stream of the buffer, and the optical density of the product of 


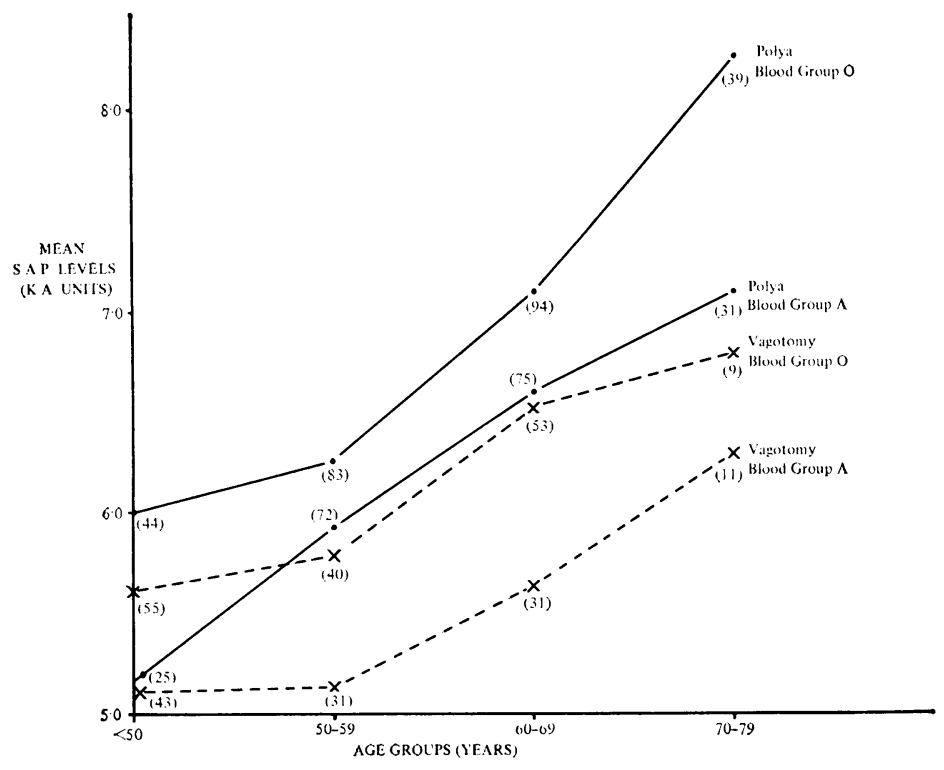

Fig. 1 The mean $S A P$ (range 3.0-11.5 KA units $/ 100 \mathrm{ml}$ ) in relation to operation, age, and blood group. The figures in parentheses indicate the numbers of men in each group.

\begin{tabular}{llll}
\hline Source & Estimate of Variance & Variance Ratio & Significance (P) \\
\hline Between operations (M) & 23.280625 & 9.19 & $<0.01$ \\
Between blood groups (F) & 20.475625 & 9.08 & $<0.01$ \\
Between age groups (C) & 36.327292 & 14.34 & $<0.005$ \\
M $\times$ F interaction & 0.950625 & 0.38 & $>0.05$ \\
M C interaction & 1.570625 & 0.62 & $>0.05$ \\
F $\times$ C interaction & 1.402292 & 0.55 & $>0.05$ \\
M $\times$ F C C interaction & 2.210625 & 0.87 & $>0.05$ \\
Residual & 2.534010 & & \\
\hline
\end{tabular}

Table I Analysis of variance in men aged 40 to 65 years

\begin{tabular}{|c|c|c|c|c|c|c|c|c|}
\hline \multirow[t]{4}{*}{ Age } & \multicolumn{4}{|l|}{ Polya } & \multicolumn{4}{|c|}{ Vagotomy and Drainage } \\
\hline & \multicolumn{4}{|c|}{ Blood Group } & \multicolumn{4}{|c|}{ Blood Group } \\
\hline & \multicolumn{2}{|l|}{$O$} & \multicolumn{2}{|l|}{$\boldsymbol{A}$} & \multicolumn{2}{|l|}{$O$} & \multicolumn{2}{|l|}{$A$} \\
\hline & $\begin{array}{l}\text { Total } \\
\text { in Group }\end{array}$ & $\begin{array}{l}\text { Raised } \\
\text { SAP }\end{array}$ & $\begin{array}{l}\text { Total } \\
\text { in Group }\end{array}$ & $\begin{array}{l}\text { Raised } \\
\text { SAP }\end{array}$ & $\begin{array}{l}\text { Total } \\
\text { in Group }\end{array}$ & $\begin{array}{l}\text { Raised } \\
\text { SAP }\end{array}$ & $\begin{array}{l}\text { Total } \\
\text { in Group }\end{array}$ & $\begin{array}{l}\text { Raised } \\
\text { SAP }\end{array}$ \\
\hline $\begin{array}{l}35-49 \\
50-59 \\
60-69 \\
70+\end{array}$ & $\begin{array}{l}44 \\
83 \\
94 \\
39\end{array}$ & $\begin{array}{c}1 \\
6 \\
7 \\
11\end{array}$ & $\begin{array}{l}25 \\
72 \\
75 \\
31\end{array}$ & $\begin{array}{l}1 \\
2 \\
3 \\
4\end{array}$ & $\begin{array}{l}55 \\
40 \\
53 \\
9\end{array}$ & $\begin{array}{l}0 \\
0 \\
0 \\
2\end{array}$ & $\begin{array}{l}43 \\
31 \\
31 \\
11\end{array}$ & $\begin{array}{l}0 \\
0 \\
0 \\
1\end{array}$ \\
\hline
\end{tabular}

Table II The frequency of marginally raised $S A P$ levels $(12 \cdot 0-17 \cdot 0 \mathrm{KA}$ units $/ 100 \mathrm{ml})$ in relation to age, blood group, and type of operation this reaction was measured directly at $410 \mathrm{~m} \mu$ at the $p \mathrm{H}$ of the reaction mixture. The method was simple and quick to operate and no colour reagent, series of serum blank estimations was necessary.

The method was calibrated in KA units using calf intestinal enzyme standards (Ambler and Brittain, 1967). The use of enzyme standards allowed for the compensation of any small daily changes in the automated method. The estimation in 30 male volunteers, under the age of 55, from the laboratory staff indicated the normal range to be $3 \cdot 0-11 \cdot 5 \mathrm{KA}$ units $/ 100$ millilitres.

The ABO blood group of the patients was determined by a standard agglutination method.

\section{Results}

The mean values for SAP for range 3.0-11.5 KA units are summarized in relation to age, type of operation, and blood group in Figure 1. The factors of age, operation, and blood group would appear to exert some effect on the mean serum alkaline phosphatase value.

An analysis of variance was carried out on the findings for men aged between 40 and 65 seen in 1966 and 1967. Normal equivalent deviate plots showed that the incidence in each age group approximated to normal distributions. In order to simplify the statistics, it was necessary to limit the number of patients to 25 who were randomly selected in each age group. From the results of the study (shown in Table I) it was concluded that the mean SAP was affected by age, operation, and blood group, which caused a highly significant difference in the mean values, and that there was no interaction between the three factors; they acted separately and were not modified one by another.

During the period 1966 to 1967,35 men with partial gastrectomy and three with vagotomy and drainage had values of $12 \cdot 0-17 \cdot 0 \mathrm{KA}$ units $/ 100 \mathrm{ml}$ (Table II). The difference in the distribution of such values between partial gastrectomy and vagotomy and drainage was highly significant $(\mathrm{P}<0.005)$.

In the partial gastrectomy group, the frequency of the marginally raised values increased with age $(P<0.001)$; furthermore these values were found to be more common in blood group $\mathrm{O}$ than in $\mathrm{A}$, the difference being just significant $(\mathrm{P}<$ 0.05 ). Fourteen of these men, all well and free of symptoms, were studied in 1966,1967 , and 1968 , the mean values being very similar, $13 \cdot 5,13 \cdot 0$, and $13.0 \mathrm{KA}$ units $/ 100 \mathrm{ml}$. The individual values were also similar (Table III).

In 18 men, the SAP level was over $17.0 \mathrm{KA}$ units and this group differs from the previous group in that, although the frequency increases with age $(\mathrm{P}<0.05)$ there was no relationship with either operation ( $P>0.05$ ), or blood group 


\begin{tabular}{|c|c|c|c|}
\hline \multirow[t]{2}{*}{ Patient } & \multicolumn{3}{|c|}{$S A P$ Level of Patient (KA units) } \\
\hline & 1966 & 1967 & 1968 \\
\hline 1 & 13.0 & $12 \cdot 0$ & 15.0 \\
\hline 2 & 15.0 & 12.5 & 12.5 \\
\hline 3 & 12.5 & $13 \cdot 0$ & 12.5 \\
\hline 4 & $15 \cdot 5$ & 13.0 & 15.0 \\
\hline 5 & 13.0 & 12.0 & 12.0 \\
\hline 6 & 15.5 & 12.5 & 11.5 \\
\hline 7 & 13.0 & 14.0 & 12.0 \\
\hline 8 & 14.0 & $12 \cdot 0$ & 16.0 \\
\hline 9 & 13.0 & 14.5 & 13.5 \\
\hline 10 & 12.5 & 12.5 & 11.0 \\
\hline 11 & $12 \cdot 0$ & 14.5 & 12.5 \\
\hline 12 & 15.0 & 12.0 & 12.0 \\
\hline 13 & 14.5 & 15.5 & 15.5 \\
\hline 14 & $12 \cdot 3$ & $12 \cdot 0$ & $11 \cdot 0$ \\
\hline $\begin{array}{l}\text { Mean SAP } \\
\text { level } \pm \mathrm{SE}^{1}\end{array}$ & $13 \cdot 5 \pm 0.31$ & $13.0 \pm 0.36$ & $13.0 \pm 0.50$ \\
\hline
\end{tabular}

Table III The results from 14 patients with marginally raised SAP levels who were reinvestigated during the three years of the survey

${ }^{1}$ Standard error of the mean.

(P > 0.05). Sixteen men had Paget's disease of the bone and two had liver disease.

\section{Discussion}

Metabolic bone disease following gastrectomy has stimulated interest in serum alkaline phosphatase, and several investigators (Jones et al, 1962; Deller et al, 1963; Clark, 1964) have measured the enzyme as a screening test for osteomalacia in patients with gastrectomy.

The basically accepted normal upper limit is 13.0 KA units/100 ml (Wooton, King, and Smith, 1951), but Clark, Beck, and Shock (1951), Hobson and Jordan (1959), and Klaassen and Sierstsema (1964) have shown that the average SAP increases with age after the age of 50 , and values of $16 \cdot 0$ KA units are not uncommon in patients over 60 years.

In a survey of patients submitted to gastric surgery in York, Morgan et al (1965) found that a cause for values over 17.0 KA units could usually be demonstrated, but values in the range $12 \cdot 0$ 17.0 KA units were largely unexplained. They suggested, on the basis of the findings of Bamford, Harris, Luffman, Robson, and Cleghorn (1965), that such marginally raised levels might be due to the intestinal fraction; however, Pulvertaft et al (1967) were unable to confirm this hypothesis.

The present study shows that, in the range 3.01$2.0 \mathrm{KA}$ units, the average value increases with age in men over the age of 50 who have undergone surgery for peptic ulceration; this increase was observed following Polya type gastrectomy and vagotomy and drainage. Following either type of operation the average was higher for men with blood group $\mathrm{O}$ than for those with blood group A. Presumably this is due to the intestinal fraction. For both blood groups, however, the average was higher following gastrectomy than after vagotomy and drainage; this difference is being investigated.

Values in the range $12 \cdot 0-17 \cdot 0 \mathrm{KA}$ units followed the same pattern as the lower values and were influenced by the same three factors, and it is suggested that these values represent, in general, the extreme additive effect of these factors.

We thank Professor W. Bartley of the Department of Biochemistry, University of Sheffield, for advice and guidance with the general problem, and Dr S. Braun of the Department of Probability and Statistics, University of Sheffield, for the analysis of the variance.

Please address requests for reprints to J. Ambler, Fisons Pharmaceuticals Ltd, Research and Development Laboratorics, Loughborough, Leics.

\section{References}

Ambler, J., and Brittain, M. (1967). Observations on the automated determination of alkaline phosphatase using p-nitrophenyl-phosphate as substrate. Proc. Ass. clin. Biochem., 4, 252-253.

Bamford, K. F., Harris, H., Luffman, J. E., Robson, E. B., and Cleghorn, T. E. (1965). Serum alkaline-phosphatase and the ABO blood groups. Lancet, 1, 530-531.

Clark, C. G. (1964). Post-gastrectomy bone disease. Proc. roy. Soc. Med., 57, 580-582.

Clark, L. C., Jnr., Beck, E. I., and Shock, N. W. (1951).Serum alkaline phosphatase in middle age and old age. J. Geront., 6, 7-12.

Deller, D. J., Edwards, R. G., and Addison, M. (1963). Calcium metabolism and the bones after partial gastrectomy. II, The nature and cause of bone disorder. Aust. Ann. Med., 12, 295-306.

Jones, C. T., Williams, J. A., Cox, E. V., Meynell, M. J., Cooke, W. T., and Stammers, F. A. R. (1962). Peptic ulceration. Some haemolytical and metabolic consequences of gastric surgery. Lancet, 2, 425-428.

Klaassen, C. H. L., and Sierstsema, L. H. (1964). De invloed van de leeftijd op de alkalische fosfotasewaarde in het serum. $T$. Ned, Geneesk., 108, 1433-1436.

Morgan, D. B., Paterson, C. R., Woode, C. G., Pulvertaft, C. N. and Fourman, P. (1965). Search for osteomalacia in 1228 patients after gastrectomy and other operations on the stomach. Lancet, 2, 1085-1088.

Morgenstern, S., Kessler, G., Auerbach, J., Flor, R. V., and Klein, B. (1965). An automated p-nitrophenyl phosphate serum alkaline phosphatase procedure for the AutoAnalyzer. Clin. Chem., 11, 876-888.

Pulvertaft, C. N., Luffman, J. E., Robson, E. B., Harris, H., and Langman, M. J. S. (1967). Isoenzymes of alkaline phosphatase in patients operated upon for peptic ulcer. Lancet, 1, 237-239.

Wootton, I. D. P., King, E. J., and Smith, T. M. (1951). The quantitative approach to hospital biochemistry. Brit. med. Bull. 7, 307-311.

Yong, J. M. (1966). Cause of raised serum alkaline phosphatase after partial gastrectomy and in other malabsorption states. Lancet, 1, 1132-1134. 